This is a so-called personal version (author's manuscript as accepted for publishing after the review process but prior to final layout and copyediting) of the article.

Tienari, Janne and Vaara, Eero. 2010. On the Narrative Construction of Multinational Corporations: An Antenarrative Analysis of Legitimation and Resistance in a Cross-Border Merger. Organization Science.

Researchers are kindly asked to use the official publication in references.

\title{
On the Narrative Construction of Multinational Corporations: An Antenarrative Analysis of Legitimation and Resistance in a Cross-Border Merger
}

\author{
Janne Tienari \\ and \\ Eero Vaara \\ Hanken School of Economics, FI-00101 Helsinki, Finland; and \\ Strategy and Organization Department, EMLYON Business School, 69132 Ecully, France, \\ eero.vaara@hanken.fi
}




\section{Abstract}

Although extant research has highlighted the role of discourse in the cultural construction of organizations, there is a need to elucidate the use of narratives as central discursive resources in unfolding organizational change. Hence, the objective of this article is to develop a new kind of antenarrative approach for the cultural analysis of organizational change. We use merging multinational corporations (MNCs) as a case in point. Our empirical analysis focuses on a revelatory case: the financial services group Nordea, which was built by combining Swedish, Finnish, Danish, and Norwegian corporations. We distinguish three types of antenarrative that provided alternatives for making sense of the merger: globalist, nationalist, and regionalist (Nordic) antenarratives. We focus on how these antenarratives were mobilized in intentional organizational storytelling to legitimate or resist change: globalist storytelling as a means to legitimate the merger and to create MNC identity, nationalist storytelling to relegitimate national identities and interests, Nordic storytelling to create regional identity, and the critical use of the globalist storytelling to challenge the Nordic identity. We conclude that organizational storytelling is characterized by polyphonic, stylistic, chronotopic, and architectonic dialogisms and by a dynamic between centering and decentering forces. This paper contributes to discourse-cultural studies of organizations by explaining how narrative constructions of identities and interests are used to legitimate or resist change. Furthermore, this analysis elucidates the dialogical dynamics of organizational storytelling and thereby opens up new avenues for the cultural analysis of organizations.

Key words: multinational; merger; acquisition; integration; culture; identity; discourse; narrative; storytelling; antenarrative; polyphony; heteroglossia; power; ideology

History: Published online in Articles in Advance.

\section{Introduction}

Discourses play a central role in the cultural construction of organizations. Extant research has highlighted how cultural toolkits (Swidler 1986, Weber 2005), vocabularies of sensemaking (Weick 1995, Geppert 2003), frames (Goffman 1974, Fiss and Hirsch 2005), and genre repertoires (Orlikowski and Yates 1994, Levina and Orlikowski 2009) are used as discursive resources to make sense of organizations. We wish to add to this body of literature by elucidating the use of narratives as central discursive resources in times of change. Although the concepts of discourse and narrative are often overlapping and used interchangeably, it is important to focus special attention on narratives because they provide 
means for making temporal sense of organizations - for constructing a sense of the past, present, and/or future of the organization (Czarniawska 2004). Furthermore, narratives are used in purposeful storytelling to give sense to change and to manage meaning (Gabriel 2000, Boje 2008, Sonenshein 2010).

However, the full potential of the narrative approach has not been realized in cultural analyses of organizations. This is at least partly due to a lack of conceptual frameworks and methods that would facilitate analysis of narratives and storytelling in action, as they are used in organizations undergoing change. For this purpose, we draw from antenarrative analysis (Boje 2001, 2008), which has been developed on the basis of Bakhtin's ideas (1981, 1984). Antenarrative analysis does not focus on fully formed stories as in classical literary narrative analysis; antenarratives are instead conceptualized as fragments of organizational discourse that construct identities and interests in time and space. This approach is ideal for an analysis of narrative sensemaking and storytelling as they unfold over time in organizations undergoing change. By drawing on Bakhtin (1981, 1984), we emphasize that there can be alternative and competing antenarratives of organizational change. These antenarratives may exist in a dialogical relationship, that is, as mutually constitutive constructions that each serve specific purposes.

Hence, the objective of this article is to develop a new kind of antenarrative approach to be used in cultural analysis of organizational change. We use merging multinational corporations (MNCs) as a case in point. MNCs are particularly interesting organizations because of their inherent cultural complexity (Geppert 2003, Brannen 2004, Jack et al. 2008) and complicated institutional environment (Kostova and Zaheer 1999, Kostova et al. 2008). In particular, MNCs have to deal with contradictory pressures related to globalization on the one hand and national interests on the other. These are often expressed in alternative and competing narratives about the MNC and its future. This is especially the case when new MNCs are formed in international mergers and acquisitions. These new MNC organizations are characterized by internal politics and cultural clashes (Olie1994, Ailon-Suday and Kunda 2003, Stahl and Mendenhall 2005). Furthermore, they tend to involve struggles of legitimacy where management of meaning plays a central role (Tienari et al. 2003, Vaara et al. 2006). Although prior studies have acknowledged the constitutive role of discourse in such mergers, little is known about narratives and storytelling in this context. In particular, there is a paucity of knowledge regarding how narratives are used to legitimate or resist change in unfolding merger processes. 
In our empirical analysis, we focus on a revelatory case: the Nordic financial services group Nordea, which was built through a cross-border merger combining Swedish, Finnish, Danish, and Norwegian corporations. Our study is based on extensive real-time data concerning sensemaking and storytelling. In this paper, we first identify and elaborate on three types of antenarrative that provided alternative ways for making sense of the merger; these are the globalist, nationalist, and Nordic antenarratives. We then proceed to examine the ways in which these antenarratives were mobilized in organizational storytelling to legitimate or resist change within the postmerger organization. This leads us to conclude that such storytelling is inherently dialogical in the form of polyphonic, stylistic, chronotopic, and architectonic dialogisms (Boje2008). Finally, we emphasize the dynamic of centering and decentering forces in organizational storytelling, which can be conceptualized as "heteroglossia" (Bakhtin 1981, Boje 2008).

Our paper contributes to extant understanding of the cultural construction of organizations by providing a framework that explains how narrative resources are used in sensemaking and purposeful storytelling in unfolding organizational change processes. By so doing, this framework elucidates an important aspect of cultural constructions that has not received adequate attention in previous research: how narrative constructions of identities and interests are used to legitimate or resist change. Furthermore, this analysis helps to comprehend the dialogical dynamics of organizational storytelling, that is, how exactly alternative and competing narrative constructions are linked together in organizational sensemaking. Although our analysis focuses on merging MNCs, we argue that it opens up new avenues in discourse-cultural studies more generally.

\section{An Antenarrative Approach to MNCs}

\section{Discourse and Narratives in MNCs}

Research on MNCs has focused a great deal of attention on the inherent complexity of these organizations. Cultural analyses of MNCs have concentrated on national cultural differences and the various kinds of organizational and managerial challenges that arise from these differences (Hofstede 1980, Leung et al. 2005). This stream of research has typically treated cultural differences as "objects" or "facts," and it is only recently that scholars have started to analyze the discursively constructed nature of cultural conceptions and their implications (Jack 2004, Ailon 2008, Frenkel 2008). 
There are, however, interesting openings. Although not focusing particularly on the international aspects, Boje's analyses of Disney (1995) and Enron (Boje et al. 2004) provide conceptual models and empirical illustrations of the constitutive role of narratives in and for MNCs. Geppert (2003) develops a sensemaking perspective on MNCs and pointed out how "discursive framings" of new global challenges tend to vary depending on the national cultural contexts within the multinational organization. Brannen (2004) outlines a semiotic perspective on internationalizing MNCs. Her analysis shows how national cultural differences and foreignness may be experienced as negative or positive depending on the process of recontextualization and the "semiotic fit." Frenkel (2008), in turn, adopts a postcolonial perspective based on the work of Bhabha (1990) on management discourse in cross-national knowledge transfer within MNCs. Her critical theoretical analysis reveals how this discourse is more complex than usually assumed - involving "mimicry," "hybridity," and the "third space" (in-between the colonizer and the colonized). Despite these advances, our understanding of the central role of narratives and storytelling in MNC organizations is still limited. For this purpose, we now focus on a specifically interesting case of organizational change: the creation of new MNCs through international mergers and acquisitions.

\section{International Mergers and Acquisitions}

Extant research on mergers and acquisitions has frequently explained problems and failures by focusing on postmerger integration. This has included analyses of value creation (Haspeslagh and Jemison 1991, Larsson and Finkelstein 1999, Schweizer 2005, Shaver 2006) as well as studies of human resource (Schweiger and DeNisi 1991, Greenwood et al. 1994) and cultural challenges in integration (Buono and Bowditch 1989, Stahl and Voigt 2008). In international settings, researchers have focused on national cultural differences and their impact on postmerger integration (Olie 1994, Lubatkin et al. 1998, Stahl and Mendenhall 2005). Recent studies have broadened this perspective by emphasizing identity building as a constitutive process through which conceptions of "us" and "them" are constructed (AilonSuday and Kunda 2003, Maguire and Phillips 2008). For example, Ailon-Suday and Kunda (2003) demonstrate how national identities were used as resources in politicized sensemaking in Israeli-American cases. Vaara (2002) shows how retrospective accounts by managers drew from various discourses to construct specific images of success and failure. Nationalistic discourses were central resources in these narratives, and they were often deliberately used to blame others. Riad (2005), in turn, analyzes the purposeful use of cultural discourse to promote particular ideas in postmerger integration. 
Researchers have also examined the legitimation of mergers and acquisitions. Demers et al. (2003) show that legitimation can be based on different foundations: tradition, means-ends rationality, charisma, or value rationality. In their analysis of a college merger in the United Kingdom, Brown and Humphreys (2003) find that senior managers told legitimating narratives of epic change, whereas their subordinates resisted and told tragic stories. Tienari et al. (2003) examine the ways in which rationalistic and nationalistic discourses were used in the media to frame a contested international acquisition and how stakeholders mobilized these discourses to pursue their own interests. In another media analysis, Vaara et al. (2006) study the various kinds of strategies used to legitimate a controversial merger. In a recent analysis of a failed merger, Vaara and Monin (2010) show how discursive legitimation is a key part of the merger process. Their case study explained how powerful legitimation efforts can lead to perceptions of illusionary synergies and, ultimately, to legitimacy crises. These analyses have highlighted the central role of discourse in international mergers and acquisitions. Despite these advances, however, we lack theoretical models and empirical analyses that would elucidate how exactly narratives and storytelling are used in unfolding merger processes. Hence, we now turn to antenarrative analysis as a useful theoretical and methodological perspective.

\section{An Antenarrative Perspective}

Narrative approaches to organizations have become increasingly popular (Czarniawska 1997, 2004; Gabriel 2000; Boje 2001, 2008; Sonenshein 2010). Van Maanen (1988) contends that narratives are not only a legitimate form of explanation but also the most appropriate vehicle for representing actions and events in organizations. Czarniawska (2004) states that narratives are the main source of knowledge in organizations for both organizational actors and for observers such as researchers. However, narrative approaches and methods vary significantly. For example, Boje et al. (2001) distinguish living story, realist, formalist, pragmatist, social constructionist, post-structuralist, critical theorist, and postmodernist narratological approaches.

We draw from the antenarrative approach (Boje 2001, 2008). This perspective focuses attention on antenarratives as essential means of organizational sensemaking on the one hand and on storytelling as the activity through which these antenarratives are mobilized on the other hand. Antenarratives, just like other discourses, build on available discourse-cultural resources (Swidler 1986) or vocabularies of sensemaking (Weick 1995). This means that specific attention should be focused on discursive microelements such as metaphoric 
expressions that play a crucial role in creating meanings. The process of storytelling, then, is a form of framing (Goffman 1974, Fiss and Hirsch 2005) where antenarratives are used more or less purposefully to create specific meanings and especially to construct identities and interests.

An antenarrative approach is a fruitful perspective for our purposes because narratives of organizational change are rarely coherent stories. Instead, they are often fragments of discourse that are articulated to make sense of things or to give sense to them in chaotic organizational reality. Rather than focusing on conventional narrative analysis of relatively salient structures, plots, and actants (Gabriel 2000, Greimas 1987), one should zoom in on the fragmented pieces of discourse - antenarratives - that create specific kinds of meanings. In our case, particularly interesting are, for example, metaphoric projections of future interests nd cultural stereotypes that are used in identity constructions.

Unlike conventional retrospective narrative analysis, an antenarrative approach allows one to focus on ongoing prospective sensemaking and sensegiving, how storytelling is used in action to promote or resist specific kinds of change. Boje (2008, pp. 13-14) explains it as follows:

Forward-looking antenarratives are the most abundant in business, yet the most-overlooked in research and consulting practice. These fragile antenarratives, like the butterfly, are sometimes able to change the future, to set changes and transformations in motion that have an impact on the big picture. More accurately, antenarratives seem to bring about a future that would not otherwise be.

Consistent with this approach, we will in the following focus on "storytelling episodes," that is, on fragments of communication, conversation, or text that construct identities and interests in time and space.

There are usually various alternative antenarratives in and around MNCs. Accordingly, an indepth analysis must take into account "dialogicality" in organizational storytelling (Bakhtin 1981, 1984, 1986; Hazen 1993; Boje 2008); in other words, different antenarratives tend to coexist because they provide alternative and competing versions of organizational reality and change. By drawing on Bakhtin's ideas (1981), Boje (2008) has advanced a multifaceted view on "dialogisms" in organizational storytelling, which we wish to develop further in this paper. First, antenarratives deal with "polyphony" in the form of multiple voices (Hazen 1993). In particular, antenarratives tend to give voice to specific actors and legitimate their worldviews and interests-and not others. Second, antenarratives manifest "stylistic dialogisms." This means that the styles used in antenarratives tend to include various modes 
of representation (including visual semiosis) that all contribute to ongoing organizational storytelling. Third, antenarratives are often built around specific "chronotopes," or space-time configurations. The point is that antenarratives construct specific understandings of the past, present, and future and thus place the merging MNC into a particular environment. Fourth, one can also identify "architectonic" dialogisms in the form of interplay between various cognitive, aesthetic, and ethical discourses. We will in the following sections focus on globalization and nationalism as alternative architectonic discourses that are reflected in antenarrative storytelling.

These dialogisms are also related to heteroglossia (Bakhtin 1981). This Bakhtinian concept has been recently redefined by Boje $(2008$, p. 194) to mean "the interplay of centripetal (centering) and centrifugal (decentering) forces of language." In our framework, organizational storytelling tends to involve a dynamic of antenarratives put forth to "control" the meaning of events and changes as well as other antenarratives challenging or breaking that control apart. For our purposes, it is interesting to focus attention on the dynamics of control and resistance as part of ongoing storytelling in merging MNCs.

In merging MNCs, antenarratives are not arbitrary constructs but reflect broader discourses and ideologies. We argue that MNCs as organizations are based on globalization and nationalism as constitutive discourse $\mathrm{s}$ and ideologies. On the one hand, we can see that MNCs are both products and agents of globalization (Guillén 2000, Fiss and Hirsch 2005). Consequently, there are often various kinds of globalization antenarratives circulating around MNCs. Such antenarratives are also likely to be used to make sense of mergers and acquisitions that create new MNCs. For example, discursive strategies such as the inevitability of internationalization (Leonardi and Jackson 2004) or the emphasis on synergies derived from internationalization (Vaara et al. 2006) can be seen as manifestations of globalization antenarratives. In fact, one can assume that positive globalization antenarratives often provide the basis for the legitimation of international mergers and acquisitions.

On the other hand, nationalistic antenarratives frequently appear in and around MNCs and often provide a very different kind of basis for change and identity building. Although nationalism has been examined in other fields (Anderson 1983, Billig 1995, Hobsbawm 1990), it has unfortunately received little explicit attention in MNC research (Cooper et al. 1998, Ailon-Suday and Kunda 2003). Nevertheless, as shown in the previous section, studies on international mergers and acquisitions have illustrated the importance of nationalistic 
identity building in postmerger organizations (Ailon-Suday and Kunda 2003) and the crucial role of nationalistic framings put forth in the media (Hellgren et al. 2002, Tienari et al. 2003). Although nationalism may be used for various purposes, it is important to note that nationalist antenarratives may often become powerful vehicles for promotion of change or resistance to it, depending on the assumed implications for assumed national interests.

We wish to complement this view with regionalism as a third potentially important discourse and ideology in the MNC context. Regionalism is argued to be an efficient substitute for illfunctioning multilateral institutions (Bhagwati 1991, Rugman and Verbeke 2004) as well as a basis for a new kind of identity building (Breakwell and Lyons 1996). In international mergers and acquisitions, regionalism can provide a new basis for identification and creation of joint culture that is distinctively different from globalist or nationalist discourses. This leads us to summarize our theoretical framework (see Figure 1). The crucial theoretical point is that antenarratives related to globalization, nationalism and regionalism are discursive cultural resources used to make sense of unfolding changes in and around the merging MNCs. These available resources can also be mobilized in purposeful organizational storytelling within the merging MNCs. This intentional storytelling is important because it is an essential part of the legitimation of change within the organization and of resistance to it. This storytelling is not univocal or linear, but it involves dialogisms and heteroglossia that characterize the merging MNC.

To illustrate the value of the theoretical framework offered, we now turn to our case analysis: the construction of the Nordea financial services corporation through cross-border mergers. This leads us to formulate our research questions as follows: What kinds of antenarratives serve as cultural resources in sensemaking around the merging MNC? How do the organizational actors mobilize these antenarratives in intentional storytelling to promote or resist identities and interests? What kinds of dialogical dynamics characterize this storytelling? FIGURE 1 


\section{Research Design, Empirical Materials, and Methodology}

\section{Research Design}

Our study is based on an in-depth analysis of the creation of the Nordea financial services group in 1999-2002. Nordea can be seen as a revelatory case (Miles and Huberman 1994, Yin 2005) that allows one to examine in detail the role of antenarratives and storytelling in and around the merging MNC. This is because the Nordea case involved a merger across four nations (Sweden, Finland, Denmark, and Norway) and was characterized by intense discussion in arenas internal and external to the organization. Furthermore, it is generally considered a pioneering constellation in the European financial services industry because of the complexity of the integration process. The purpose of our analysis is not to focus on the unique features of this case but to use it for analytical purposes, for obtaining findings that upon due reflection can be generalized beyond the particular case (Tsoukas 1989, Langley 1999).

Figure 1 Theoretical Framework: Antenarrative Perspective on MNCs

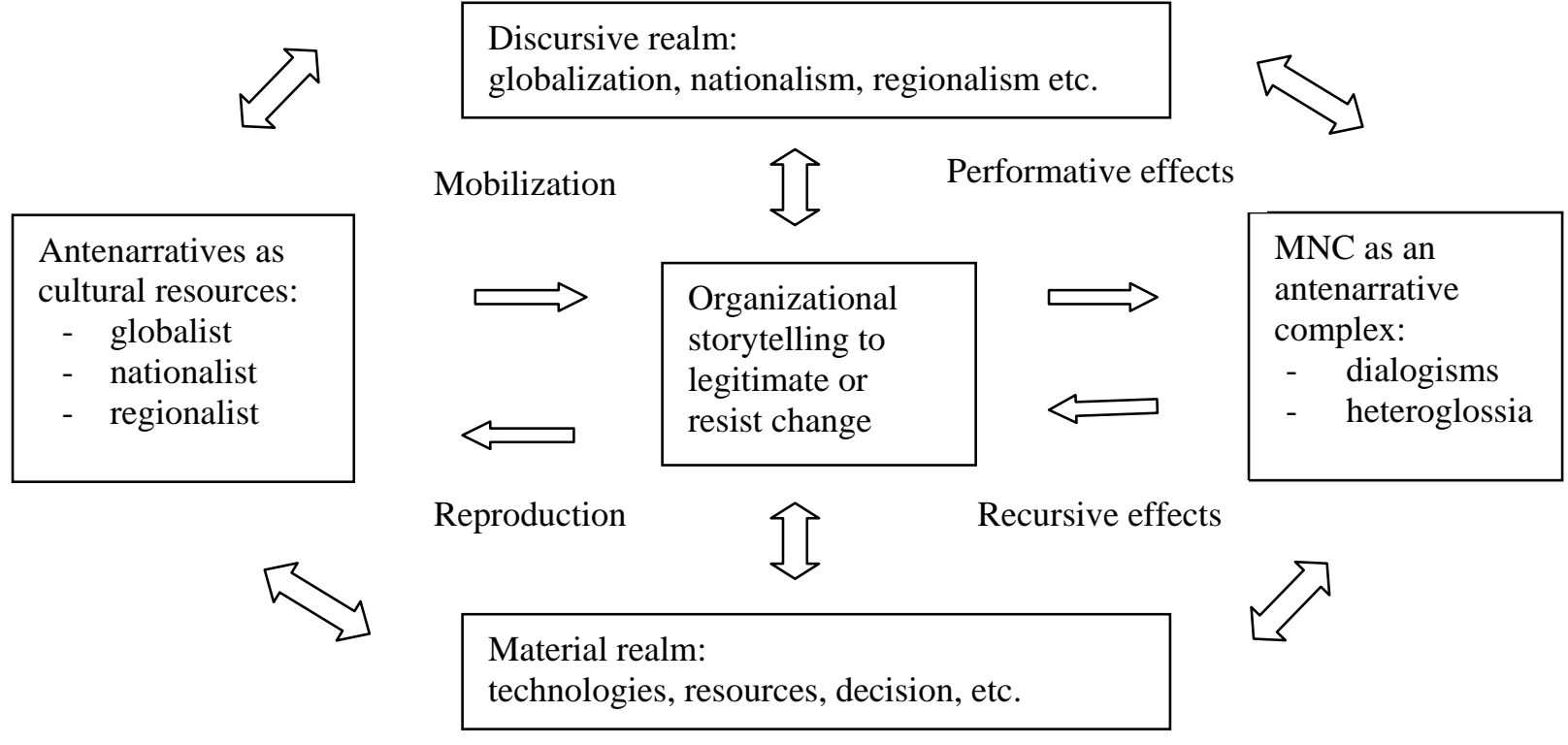

Nordea was created through a series of cross-border mergers or acquisitions. The first crossnational merger, between the Finnish Merita Bank and the Swedish Nordbanken, was announced in October 1997. The second international merger took place between MeritaNordbanken and the Danish Unidanmark in March 2000. After complex negotiations that had already started before this merger, the Norwegian CBK was acquired in October 
2000. Following the example of the actual decision makers and the media, we will consider this complex case as one merger that was consummated at the end of 2000.

Our empirical analysis was conducted in a pan-Nordic research project involving scholars from Sweden, Finland, Denmark, and Norway. We analyzed changes in the merging MNC in real time between 1999 and 2002, which provided us with direct access to sensemaking and storytelling in and around the organization.

Despite a critical scholarly approach, we were given open access to the corporation. In fact, one member of the research team was also a former member of the corporate executive management. In exchange, we provided feedback to the corporate management, which was wrestling with merger integration challenges. We are now proud to be able to present the Nordea case without using pseudonyms. This transparency adds to the authenticity and validity of our analysis and enhances the prospects for learning from this case.

\section{Empirical Materials}

Our analysis was based on four sources of data: media texts, company documents, interviews, and observation. First, to place this case in a broader context, we gathered and analyzed extensive media material on the Nordea case. After a wider preliminary search, we focused on media reports on Nordea in 1999-2001, that is, during the period when the MeritaNordbanken-Unidanmark merger and the acquisition of CBK were planned and executed, and postmerger integration was largely carried out. In each country, we collected media reports that dealt with Nordea (or its predecessors) and the mergers and acquisitions. To gain a broad view, we included leading daily newspapers, leading business weeklies, leading business dailies, and leading tabloids in each country. After selecting the most relevant ones for our purposes, our media material comprised 453 media texts (102 in Sweden, 138 in Finland, 121 in Norway, and 92 in Denmark) that we then analyzed carefully to develop an understanding of the role of antenarratives in the public sensemaking around this case.

Second, company documents provided us with important firsthand evidence of storytelling at Nordea. This material comprised press releases, plans, annual reports, minutes of meetings, management's presentations and slide shows, and personal memos that helped us to examine examples of decision making and legitimation in more detail. In addition, we gathered plans, advertisements, figures, and booklets on the launching of the identity- and brand-building 
campaign, which were crucial for our analysis. Altogether, this material comprised more than 100 documents.

Third, interviews conducted with key corporate decision makers provide the basis for our analysis. A total of 55 interviews were conducted between 2000 and 2002. These covered all but one of the top and second-tier executives of the corporation as well as a selected group of managers in middle management positions. The idea was to employ a "storytelling" approach with the use of a semistructured interview guide (Czarniawska 2004). Hence, to the extent possible, we aimed at hearing the interviewee's own stories of the changes and their implications. All interviews were carried out by researchers representing the same nationality as the interviewee and were conducted in a shared native tongue (Swedish, Finnish, Danish, or Norwegian). This was a key part of the research design because it allowed the interviewer and interviewee to engage in a process of co-authoring based on shared understandings related to national culture (Bakhtin 1984). All interviews were later fully transcribed. In addition, we interviewed two external consultants involved in Nordea's Nordic identity- and brand-building campaign.

Fourth, the research project involved cooperation between the researchers and the corporate management. One member of our research team was a member of the corporate management. This provided us with numerous opportunities to observe organizational sensemaking and to discuss various issues with corporate representatives in informal settings. In addition, scheduled meetings and informal encounters between Nordea's managers and our research team members provided insights and served to validate our interpretations.

\section{A Multimethod Antenarrative Analysis}

Our analysis is based on antenarrative methodology (Boje 2001). Our research approach was abductive because it involved constant movement between theory and empirical material (Van Maanen et al. 2007). Accordingly, theoretical ideas were developed alongside increasingly detailed mapping of the case. Our analysis proceeded in stages. After preliminary analyses, we focused on antenarratives and intentional storytelling. First, we focused on the question of which kinds of antenarratives characterized sensemaking around this case. Our preliminary analyses had led us to focus on three important and different antenarratives: globalist, nationalist, and Nordic. On this basis, we conducted a thorough analysis of the media texts to validate and further examine the prevalence of these antenarratives in the media accounts. In brief, the idea was to focus on the media as a central 
(but obviously not the only) arena for sensemaking. Two persons coded the material to examine whether any of the three antenarratives characterized the texts. This coding was iterative, and we developed the coding categories until we reached a $90 \%$ intercoder agreement with a subsample of 30 texts; that is, the coders agreed upon at least $90 \%$ of the codings for the three categories. As a result, we found globalist antenarratives in $48 \%$ of the texts (Sweden 46\%, Finland 42\%, Denmark 60\%, and Norway 49\%), nationalist antenarratives in 35\% of the texts (Sweden 32\%, Finland 31\%, Denmark 38\%, and Norway 40\%), and Nordic antenarratives in 48\% (Sweden 42\%, Finland 52\%, Denmark 50\%, and Norway $45 \%$ ) of the texts. This analysis confirms the widespread availability of these three antenarratives as cultural resources used in sensemaking around the MNC. We proceeded to examine details of these media texts and other available material to spell out the characteristics of the antenarrative types. Following the tradition of critical discourse analysis (Fairclough 2003), this involved close reading of the texts to identify characteristic themes, subthemes, and their linguistic expressions.

Second, we examined how these antenarratives were mobilized in intentional storytelling by organizational actors to legitimate or resist change within the merging MNC. For that purpose, we concentrated on the corporate communications and other documents, interviews, and observations. In this analysis, we focused on the managers' communication: who said what and when. We conducted a storytelling network analysis (Boje 2001, Chapter 4) to map out how specific stories were told and retold over time during our observation period. What helped a great deal was that our project was conducted in real time; the interviews and participant observations provided current material on storytelling as it unfolded. Their systematic analysis led us to distinguish myriads of storytelling episodes that we then visually mapped out in detailed storytelling networks. These networks provided a basis for focusing on a specific pattern of storytelling in the postmerger organization: corporate top management used globalist antenarratives to legitimate the merger and to create new MNC identity. These antenarratives were, however, challenged by nationalist storytelling that focused on national identities and interests. This was one of the major reasons why top management launched an extensive identity-building campaign that drew on Nordic culture and identity. These antenarratives were in turn challenged by new globalist antenarratives calling for more radical change and globalist identity.

Third, we analyzed the dialogical relationships between the stories more closely. We focused attention on how the actors' storytelling efforts were intertwined with legitimation and 
resistance. Furthermore, we proceeded to examine the polyphonic, stylistic, chronotopic, and architectonic dialogisms in the antenarratives and also the dynamic of centering and decentering storytelling (heteroglossia). This led us to refine our analyses in the previous stages to tease out examples of how storytelling had an impact on actions, decisions, and subsequent storytelling in various arenas.

This kind of antenarrative analysis involves methodological challenges. Antenarratives are ontologically and epistemologically complicated objects to study and capture. In particular, it is difficult to place specific antenarratives in the broader context and to identify patterns in organizational storytelling (Boje 2001). In our analysis, we pursued a triangulation strategy: a constant effort to compare the evidence from different sources. This kind of analysis is necessarily interpretative and subjective, which can lead to one-sided representations and conclusions. We were undoubtedly biased by our background, nationality, and relationships with people in the organization as well as by our opinions of what is right or wrong. However, working in a pan-Nordic team where researchers represented four nationalities helped us to reduce ethnocentricity. It provided apt opportunities for putting our findings into perspective and for showing evidence for our claims. Finally, it should be noted that all analyses were linguistically challenging; we had to deal with four Nordic languages and English. The initial analysis was conducted in the original language, but the main results were translated into English when comparing the findings. Although meanings and nuances were unavoidably lost in translations, the richness of the material allowed us to deal with specific problems by constant comparison of several examples.

\section{Antenarratives as Cultural Resources in Sensemaking Around the Merging MNC}

We first analyzed what kinds of antenarratives served as cultural resources in sensemaking around the merging MNC. We concentrated on the media coverage as an important sensemaking arena. We identified three types of antenarrative-globalist, nationalist, and Nordic - the characteristic features of which are summarized in Table 1.

\section{Globalist Antenarratives}

Our analysis of the media coverage around Nordea in 1999-2001 illustrates the central role of the globalist antenarratives as resources for sensemaking. Although there were some differences between the media coverage in the four countries, similar themes dominated the discussion in all four. An overarching theme in these antenarratives was the inevitability of 
global restructuring. On the one hand, this was shown in the naturalization of international mergers and acquisitions. That is, the cross-border deals were portrayed as the appropriateand at times the only - way to develop the financial services sector. On the other hand, the globalist antenarratives often anticipated future restructurings and merger or acquisition deals. In particular, it was frequently stated that Nordea needed to be on the forefront of this process if it were to survive and prosper. There was speculation about future acquisitions by Nordea. However, at times Nordea was also portrayed as a potential acquisition target. The benefits derived from international mergers and acquisitions were another key theme in the globalist antenarratives. Size and synergy were dominant tropes in the media's globalist antenarratives. Shareholder value was also frequently presented as an increasingly important objective (overriding, for example, national interests and concerns). The globalist antenarratives also focused on the intensifying competition in the financial services sector. Mergers and acquisitions were frequently described as strategic moves that resembled military maneuvers; this was apparent in the frequent use of military metaphors. In this view, mergers and acquisitions were part of an ongoing global restructuring game that involved winners and losers.

\section{Nationalist Antenarratives}

The focus in the media's nationalist antenarratives was on historical reconstructions, international confrontation, and cultural differences. Although the overall themes were similar, the actual antenarratives were different, mainly as a result of the specific roles that the respective organizations and their top managers had played in the Nordea merger but also because of the particular historical relationships between these nations.

Swedish Antenarratives. In the Swedish nationalist antenarratives, the historical reconstructions centered on the Swedish banking crisis in the early 1990s, where Nordbanken was the bank most severely hit, and the subsequent reconstruction of the organization. The local media reproduced stories about Swedes being in the driver's seat; MeritaNordbanken's CEO Hans Dalborg was singled out as the hero of Nordea and Sweden. The Swedish nationalist narratives tended to reproduce a specific kind of international confrontation. The focus was on the ability of the Swedes to expand operations in Denmark and Norway. Speculation about winners and losers was also an important part of the public discussion. Furthermore, the Swedish antenarratives frequently dealt with cultural differences in the form of representations of cultural clashes and auto- and heterostereotypes. 
Table 1 Globalist, Nationalist, and Nordic Antenarratives in the Public Discussion

\begin{tabular}{|c|c|c|}
\hline Themes & $\begin{array}{l}\text { Subthemes and tropes } \\
\text { (linguistic expressions) }\end{array}$ & Typical examples \\
\hline \multicolumn{3}{|l|}{ Globalist Antenarratives } \\
\hline \multirow[t]{2}{*}{$\begin{array}{l}\text { Inevitability of global } \\
\text { restructuring }\end{array}$} & Naturalization & $\begin{array}{l}\text { "The wave of bank mergers continues. The trend } \\
\text { towards larger units in European financial } \\
\text { services is ever more apparent" } \\
\text { (Affärsvärlden, Sweden, March 15, 2000). }\end{array}$ \\
\hline & $\begin{array}{l}\text { Anticipation of future } \\
\text { deals }\end{array}$ & $\begin{array}{l}\text { "The table is laid, Deutsche Bank. The expansion } \\
\text { that [Nordea] has sought in the Nordic region is } \\
\text { now complete, providing a good launch pad to the } \\
\text { Baltics, Poland and maybe even Northern } \\
\text { Germany. However, the restructuring in financial } \\
\text { services in the Nordic region is definitely not over } \\
\text { either" } \\
\text { (Helsingin Sanomat, Finland, October 17, 2000; } \\
\text { speculating about Nordea's future). }\end{array}$ \\
\hline \multirow[t]{3}{*}{$\begin{array}{l}\text { Benefits of international } \\
\text { mergers and acquisitions }\end{array}$} & Size & $\begin{array}{l}\text { "[I]n the next round of consolidation Nordea is } \\
\text { big enough to negotiate on equal terms with } \\
\text { European financial giants" } \\
\text { (Talouselämä, Finland, November } 17,2000 \text { ). }\end{array}$ \\
\hline & Synergies & $\begin{array}{l}\text { "MeritaNordbanken is actively trying to get hold } \\
\text { of [CBK] because the strategies of the two banks } \\
\text { provide a good fit. For example, [CBK] has an } \\
\text { extensive branch network similar to Merita's } \\
\text { According to calculations by MeritaNordbanken, } \\
\text { the integration of the two banks would provide } \\
\text { synergy benefits of } 80 \text { million Euros within three } \\
\text { years" } \\
\text { (Kauppalehti, Finland, September } 21,1999 \text { ). }\end{array}$ \\
\hline & Shareholder value & $\begin{array}{l}\text { "Prices of bank and insurance company shares } \\
\text { went up in Nordic stock exchanges on } \\
\text { Wednesday. The main reason was speculation } \\
\text { about a merger between MeritaNordbanken and } \\
\text { Unidanmark. The Finnish daily newspaper } \\
\text { Helsingin Sanomat wrote on Wednesday that } \\
\text { MeritaNordbanken and the Danish } \\
\text { Unidanmarkwer e close to reaching a merger deal } \\
\text { 16, 1999). }\end{array}$ \\
\hline Competition & Strategic maneuvers & $\begin{array}{l}\text { "With a blitz attackof over two billion krona } \\
\text { yesterday, MeritaNordbanken may be able to } \\
\text { block other offers - " } \\
\text { (Aftenposten, Norway, September } 21,1999 \text { ). }\end{array}$ \\
\hline
\end{tabular}




\begin{tabular}{|c|c|c|}
\hline \multicolumn{3}{|c|}{ Swedish antenarratives } \\
\hline \multirow[t]{2}{*}{$\begin{array}{l}\text { Historical } \\
\text { reconstructions }\end{array}$} & $\begin{array}{l}\text { Swedish banking crisis } \\
\text { and restructuring }\end{array}$ & $\begin{array}{l}\text { "The happy ' } 80 \text { s were over and Nordbanken was } \\
\text { subject to big financial problems. The state's role } \\
\text { as owner in the bank forced the state-owned } \\
\text { company Securum to take over risky loans from } \\
\text { the crisis-driven bank" } \\
\text { (Aftonbladet, June 3, 2000). }\end{array}$ \\
\hline & Heroes & $\begin{array}{l}\text { "Hans Dalborg managed to do the impossible. He } \\
\text { took over a bankrupt's estate. Today, Nordbanken } \\
\text { is the biggest. The biggest of all" } \\
\text { (Aftonbladet, October 16, 2000). }\end{array}$ \\
\hline \multirow[t]{2}{*}{$\begin{array}{l}\text { International } \\
\text { confrontation }\end{array}$} & Expansion & $\begin{array}{l}\text { "The offer itself was hardly discussed in the } \\
\text { debate. [The merger] is more about the Swedes } \\
\text { laying their hands on a large Norwegian bank" } \\
\text { (Dagens Nyheter, September 25, 1999). }\end{array}$ \\
\hline & Winners and losers & $\begin{array}{l}\text { "MeritaNordbanken won the battle over [CBK], } \\
\text { the second largest bank in Norway" } \\
\text { (Aftonbladet, October } 17,2000 \text { ). }\end{array}$ \\
\hline \multirow[t]{2}{*}{ Cultural differences } & Cultural clashes & $\begin{array}{l}\text { " } \\
\text { different nationalities set out to cooperate-not } \\
\text { least in managerial positions-with cultural } \\
\text { differences and all language blending that it } \\
\text { brings about" } \\
\text { (Affärsvärlden, March 15, 2000). }\end{array}$ \\
\hline & $\begin{array}{l}\text { Auto- and } \\
\text { heterostereotypes }\end{array}$ & $\begin{array}{l}\text { "It is difficult to deny the fact that Norwegians to } \\
\text { a higher degree than others protect their own } \\
\text { country and their own values. In sports, we } \\
\text { consider it quite adorable. In trade and industry, } \\
\text { however, it is more difficult to accept this struggle } \\
\text { for preserving 'the Norwegian'" } \\
\text { (Dagens Nyheter, September } 25,1999 \text { ). }\end{array}$ \\
\hline \multicolumn{3}{|l|}{ Finnish antenarratives } \\
\hline \multirow[t]{2}{*}{$\begin{array}{l}\text { Historical } \\
\text { reconstructions }\end{array}$} & $\begin{array}{l}\text { Finnish banking crisis } \\
\text { and } \\
\text { restructuring }\end{array}$ & $\begin{array}{l}\text { "In all four countries, you can with fear recall the } \\
\text { banking crisis of the early 1990s. The Finnish } \\
\text { UBF and Kansallis, which back then formed } \\
\text { Merita, received state subsidies that they later } \\
\text { paid back_-_" } \\
\text { (Ilta-Sanomat, October 17, 2000). }\end{array}$ \\
\hline & Heroes & $\begin{array}{l}\text { "Vainio is a man who has played an extremely } \\
\text { influential role in the birth of the Nordic bank. In } \\
\text { 1994, before Kansallis and UBF merged to form } \\
\text { Merita, the idea of a Nordic cross-border bank } \\
\text { was conceived in what backthen was UBF" } \\
\text { (Ilta-Sanomat, October 21, 2000). }\end{array}$ \\
\hline \multirow[t]{2}{*}{$\begin{array}{l}\text { International } \\
\text { confrontation }\end{array}$} & Concerns & $\begin{array}{l}\text { "An upset reader called. He maintained that we } \\
\text { Finns haven't realized that our dear neighbors the } \\
\text { Swedes are planning a big swindle. He didn't talk } \\
\text { about MeritaNordbanken's offer to acquire a } \\
\text { Norwegian bank, but rather the news about MNBs } \\
\text { organizational restructuring } \\
\text { (Helsingin Sanomat, September } 26,1999 \text { ). }\end{array}$ \\
\hline & Winners and losers & $\begin{array}{l}\text { "Sweden's Minister of Trade Björn Rosengren } \\
\text { has publicly rejoiced that MeritaNordbanken will } \\
\text { finally become a Swedish bank. Yes, indeed. The }\end{array}$ \\
\hline
\end{tabular}




\begin{tabular}{|c|c|c|}
\hline & & $\begin{array}{l}\text { bank gets a new holding company, the } \\
\text { headquarters and domicile of which is } \\
\text { Stockholm" } \\
\text { (Ilta-Sanomat, October 12, 1999). }\end{array}$ \\
\hline \multirow[t]{2}{*}{ Cultural differences } & Cultural clashes & $\begin{array}{l}\text { "It is very difficult to imagine how selfish } \\
\text { Norwegians would fit in with the Finns and } \\
\text { Swedes. Finnish bankers have enough to bear } \\
\text { with the Swedes who talk endlessly and always } \\
\text { want to look for consensus. And Norwegians and } \\
\text { Swedes have to put up with the cryptic } \\
\text { Finns" (Ilta-Sanomat, September } 21,1999 \text { ). }\end{array}$ \\
\hline & $\begin{array}{l}\text { Auto- and } \\
\text { heterostereotypes }\end{array}$ & $\begin{array}{l}\text { "When Vesa Vainio and____Hans Dalborg } \\
\text { appear together in public, they are the living } \\
\text { image of a caricature about Finns and Swedes. } \\
\text { Vainio speaks calmly and avoids drama. He is } \\
\text { strictly practical and sturdy. Dalborg, in turn, is } \\
\text { always smiling and nice. He is friendly and } \\
\text { sociable, and he wants to talk about common } \\
\text { issues" } \\
\text { (Ilta-Sanomat, October 21,2000). }\end{array}$ \\
\hline \multicolumn{3}{|l|}{ Danish antenarratives } \\
\hline \multirow[t]{2}{*}{$\begin{array}{l}\text { Historical } \\
\text { reconstructions }\end{array}$} & Danish restructurings & $\begin{array}{l}\text { "In } 1989 \text {, too, they used the argument that they } \\
\text { had to merge because corporate customers were } \\
\text { becoming bigger than the banks. A number of } \\
\text { analyses of bank mergers _-_- has since then } \\
\text { shown that mergers seldom result in increased } \\
\text { effectiveness" } \\
\text { (Berlingske Tidende, March } 8,2000 \text {; quoting an } \\
\text { expert who refers to the merger forming Unibank } \\
\text { in 1989-1990). }\end{array}$ \\
\hline & Heroes & $\begin{array}{l}\text { "Both the old friends from Lemvig and the top } \\
\text { cats in Europe's financial circles are looking } \\
\text { closely at Thorleif Krarup's work at the absolute } \\
\text { top of the financial super-league in the Nordic } \\
\text { region" } \\
\text { (Berlingske Tidende, December 30, 2000; on } \\
\text { Krarup, the fisherman's son from Lemvig). }\end{array}$ \\
\hline \multirow[t]{2}{*}{$\begin{array}{l}\text { International } \\
\text { confrontation }\end{array}$} & Conquests & $\begin{array}{l}\text { "Acquisition offers are flying like bullets between } \\
\text { banks in the Nordic region. At the moment, Danes } \\
\text { lie in the shelter from Norway's plateaus, but not } \\
\text { for much longer. In Stockholm, a new agenda has } \\
\text { been developed for the big Nordic bankwar" } \\
\text { (Jyllands-Posten, September 22, 1999). }\end{array}$ \\
\hline & Winners and losers & $\begin{array}{l}\text { "The top people in MeritaNordbanken and } \\
\text { Unidanmark celebrated the new super-merger } \\
\text { with a boost of adrenaline seldom seen in the } \\
\text { Nordic business world" } \\
\text { (Jyllands-Posten, March 8, 2000). }\end{array}$ \\
\hline Cultural differences & $\begin{array}{l}\text { Auto- and } \\
\text { heterostereotypes }\end{array}$ & $\begin{array}{l}\text { "First, the 'difficult' Norwegians will be } \\
\text { conquered___ After that, it is time for the bit } \\
\text { more merger-friendly Danes" } \\
\text { (Jyllands-Posten, November 1, 1999). }\end{array}$ \\
\hline
\end{tabular}




\begin{tabular}{|c|c|c|}
\hline \multirow[t]{3}{*}{$\begin{array}{l}\text { Historical } \\
\text { reconstructions }\end{array}$} & $\begin{array}{l}\text { Colonial history under } \\
\text { Swedish rule }\end{array}$ & $\begin{array}{l}\text { "Dagbladet has reviewed wars between Norway } \\
\text { and Sweden. Who will finally win the match } \\
\text { between Little Brother Norway and Big Brother } \\
\text { Sweden?" } \\
\text { (Dagbladet, December 13, 1999). }\end{array}$ \\
\hline & $\begin{array}{l}\text { Norwegian banking crisis } \\
\text { and restructuring }\end{array}$ & $\begin{array}{l}\text { "Norway is in danger of becoming a subsidiary } \\
\text { district in Europe's periphery" } \\
\text { (Dagbladet, November 20,1999). }\end{array}$ \\
\hline & Heroes & $\begin{array}{l}\text { "One big story of sunshine. _-_- Will Tom Ruud } \\
\text { get a seat in the top management team?-That's } \\
\text { self-evident, a happy Dalborg says" } \\
\text { (Aftenposten, October 17, 2000). }\end{array}$ \\
\hline \multirow[t]{2}{*}{$\begin{array}{l}\text { International } \\
\text { confrontation }\end{array}$} & Threats & $\begin{array}{l}\text { "Swedes take }[\mathrm{CBK}] \ldots \text { Today brings the news } \\
\text { that Dagbladet has feared: MeritaNordbanken is } \\
\text { to place an offer to buy the entire Kreditkassen. } \\
\text { The } 151 \text {-year-old Norwegian bank is to land in } \\
\text { foreign hands" } \\
\text { (Dagbladet, September 20, 1999). }\end{array}$ \\
\hline & Winners and losers & $\begin{array}{l}\text { "It is not right that Stockholm shall become our } \\
\text { financial capital"" } \\
\text { (VG, October 5, 1999; quoting CEO Svein Aaser } \\
\text { of DnB, Norway's largest bank). }\end{array}$ \\
\hline \multirow[t]{2}{*}{ Cultural differences } & Cultural clashes & $\begin{array}{l}\text { "[H]e does not agree with the suggestion that the } \\
\text { big brother-little brother complex still applies.- } \\
\text { The last ten years have been incredibly successful } \\
\text { for Norway, and we can put this discussion } \\
\text { behind us" } \\
\text { (VG, September } 25,1999) \text {. }\end{array}$ \\
\hline & $\begin{array}{l}\text { Auto- and } \\
\text { heterostereotypes }\end{array}$ & $\begin{array}{l}\text { "If the government prevents the acquisition, } \\
\text { claims of Norwegian nationalism will probably } \\
\text { rise again" } \\
\text { (VG, December 27, 1999). }\end{array}$ \\
\hline \multicolumn{3}{|l|}{ Nordic antenarratives } \\
\hline $\begin{array}{l}\text { Historical } \\
\text { reconstructions }\end{array}$ & Common heritage & $\begin{array}{l}\text { "I think it would be ideal if the four Nordic } \\
\text { countries were to be brought together under the } \\
\text { same flag. We have strong bonds, both culturally } \\
\text { and socially" } \\
\text { (Aftonbladet, Sweden, March 7, 2000). }\end{array}$ \\
\hline \multirow[t]{2}{*}{ Regionalism } & $\begin{array}{l}\text { Redefinition of home } \\
\text { market }\end{array}$ & $\begin{array}{l}\text { "In the Nordic countries the big banks have all } \\
\text { come to include } \\
\text { the entire region as their home market, rather than } \\
\text { defining the } \\
\text { home country as the home market" (Dagens } \\
\text { Naeringsliv, } \\
\text { Norway, November 29, 1999). }\end{array}$ \\
\hline & $\begin{array}{l}\text { New expressions of joint } \\
\text { identity }\end{array}$ & $\begin{array}{l}\text { "The Nordic region becomes a bankk ingdom. In } \\
\text { just a few years time, Denmark, Sweden and } \\
\text { Finland will no longer be 'abroad' for Norwegian } \\
\text { bank customers. [CBK] customers can be the first } \\
\text { to get Nordic bankcar ds. [ } ~ \\
\text { banks have also come some way towards other } \\
\text { ecoming Nordic } \\
\text { October 13, 1999). - (Aftenposten, Norway, }\end{array}$ \\
\hline
\end{tabular}




\begin{tabular}{|l|l|l|}
\hline Nordic interests & Nordic vision & $\begin{array}{l}\text { "MeritaNordbanken is well on its way to make its } \\
\text { Nordic vision a reality. At the same time, it is } \\
\text { turning its gaze towards the rest of Europe" } \\
\text { (Affärsvärlden, Sweden, March 15, 2000). }\end{array}$ \\
\cline { 2 - 3 } & Nordic project & $\begin{array}{l}\text { "Nordic union bankcomplete but for Norway" } \\
\text { (Talouselämä, Finland, March 10, 2000). }\end{array}$ \\
\cline { 2 - 3 } Equality and compromise & $\begin{array}{l}\text { "The new name Nordea...may be looked upon as } \\
\text { a compromise between a number of viewpoints, } \\
\text { and the point internally was probably for the most } \\
\text { part to irritate people as little as possible" } \\
\text { (Affärsvärlden, Sweden, November 13, 2000). }\end{array}$ \\
\hline
\end{tabular}

Most often, Swedishness was seen as the "normal" state of affairs, and others were framed as "different," even "strange."

Finnish Antenarratives. In the Finnish nationalist antenarratives, the creation of Nordea was a continuation of a longer process that had started with the Finnish banking crisis in the early 1990s. Finns referred to their own pioneering role in the process of creating the new multinational financial services company. Vesa Vainio, ex-CEO of Merita, was often presented as the mastermind behind the different steps of making Nordea. The Finnish nationalist narratives also reproduced international confrontation. A significant part of thepublic discussion dealt with national concerns. The mergers and acquisitions were portrayed as winning and losing, particularly vis-à-vis Sweden, which is often a key reference point to Finns (Finland was part of the kingdom of Sweden from 1323 to 1809). Cultural differences were also a major theme in the media coverage, involving both descriptions of cultural clashes and explicit reproduction of stereotypes. Most often, the focus was on comparison of Finns and Swedes and of Finns and Danes. Norwegians were often framed as "particularly nationalistic."

Danish Antenarratives. In the Danish nationalist antenarratives, the historical reconstructions usually started with the previous domestic Danish restructurings. Thorleif Krarup, ex-CEO of Unidanmark and the first CEO of Nordea, became the emblematic hero. International confrontation was a major theme; this was apparent in frequent speculation regarding the ultimate winners and losers in the contest between nationalities. The Danish antenarratives also frequently dealt with cultural differences in the form of auto- and heterostereotypes, which focused on comparisons between Danes and Swedes.

Norwegian Antenarratives. In the Norwegian nationalist antenarratives, the postcolonial relationship under Danish and Swedish rule was a significant theme in its own right (Norway 
was a part of Denmark from 1397 to 1814 and Sweden from 1814 to 1905). The severe domestic banking crisis of the late 1980s was then the key reference point as to how the process of consolidation began. Tom Ruud, CEO of CBK, was the main Norwegian hero in these accounts. The Norwegian nationalist antenarratives also dealt frequently with international confrontation, most often focusing on the threats posed by Swedes and Danes and speculation about winners and losers. Cultural differences were also frequently discussed in the form of descriptions of clashes and stereotypes.

\section{Nordic Antenarratives}

The Nordic antenarratives focused on the following themes: historical reconstructions, regionalism, and joint Nordic interests. The historical reconstructions tended to reproduce the joint historical and cultural heritage of the four nations, often with parallels between political cooperation between the Nordic countries and the construction of Nordea. This media coverage frequently involved regionalism, for example, in the form of redefinition of a "Nordic home market" and new expressions of joint identity. Finally, the Nordic antenarratives reproduced Nordic interests, for instance, in the form of Nordic visions, speculation regarding Nordic projects, and reflections on equality and compromise.

\section{Mobilization of Antenarratives in Intentional Storytelling in the Merging MNC}

Next, we focused on how managers mobilized these antenarratives in intentional storytelling to legitimate or resist change: globalist storytelling as a means to legitimate the merger and to create MNC identity; nationalist storytelling to relegitimate national identities and interests; Nordic storytelling to create Nordic identity; and the critical use of globalization antenarratives to challenge this Nordic identity and promote more radical globalist orientation. Table 2 summarizes the key features of this intentional storytelling.

\section{Globalist Storytelling as a Means to Legitimate the Merger and to Create MNC Identity}

When building the new financial services group, the new corporate top management faced a tremendous challenge to legitimate the merger in external and internal arenas. For this purpose, corporate managers often reverted to globalist storytelling. Consequently, the official communications regarding the merger between MeritaNordbanken and Unidanmark, as well as the subsequent acquisition of $\mathrm{CBK}$, concentrated on the justification of the international orientation. For example, the influential "Merger Prospectus" document (2000, 
p. 25) ${ }^{1}$ regarding the merger between MeritaNordbanken and Unidanmark spelled out the following justifications for the merger:

- "The globalisation of capital markets, industries and services continues to change rules of competition in virtually all industries."

- "Internationalisation...drives demand for more sophisticated and specialised financial solutions."

- "The deregulation of financial services _ _ _ and the formation of the European Economic and Monetary Union opens opportunities for restructuring of the industry not only within countries but also across national borders."

- "The rapid development of information technology is an underlying driver of change impacting bank and insurance companies _ _ _ impacting customer relations and service production and distribution."

- "Focus on shareholder value creation drives a continuous search for cost cuts, increased productivity and earnings growth."

At the same time, the corporate management faced a challenge in turning the previously separate national organizations into "a proper MNC organization." In subsequent communications, plans, and presentations, Nordea's top managers drew from the globalist antenarratives. This storytelling was notably future-oriented, with its audience consisting of business analysts, large corporate clients, the media, and - probably most importantly-key managers in charge of postmerger integration within the group. For example, Nordea's press releases in 2000-2001 focused on issues such as the development of the international organizational structure of the group and its units, appointment of key top managers in charge of international operations, planning to transfer best practices related to services and products across national boundaries, reporting on good performance and excellent prospects, informing stakeholders about prospective upgrades in the credit ratings, and making further acquisitions in the Baltic States, Poland, Russia, and Sweden. In internal communications (e.g., official plans and slideshows), the emphasis was on the inevitability of an international and shareholder oriented outlook in the new competitive landscape, the need to develop synergies across national boundaries, the plan to build a coherent and streamlined international group structure, and the importance of cross-border learning. The enthusiastic way in which these plans and decisions were communicated conveyed an image of a forwardlooking Nordea, well equipped to succeed in the global financial services industry. In all, the 
corporate management's globalist storytelling both drew from and influenced the media coverage around the case. Interestingly, one can interpret this storytelling as a means not only to control sensemaking around the merger by promoting specific globalist views as the "official truth" but also to silence of alternative interpretations - such as nationalism — within the corporation.

Table 2 Intentional Storytelling in Nordea

\begin{tabular}{|c|c|c|c|}
\hline Time & Key Storylines & $\begin{array}{l}\text { Legitimation/resistance } \\
\text { of identities and } \\
\text { interests }\end{array}$ & Protagonists \\
\hline $\begin{array}{l}\text { Initial globalist } \\
\text { storytelling } \\
\text { Spring-summer } \\
2000\end{array}$ & $\begin{array}{l}\text { - Nordea is part of the } \\
\text { globalization of } \\
\text { financial services. } \\
\text { - The key challenge is to } \\
\text { reap the benefits of the } \\
\text { cross-border merger. }\end{array}$ & $\begin{array}{l}\text { - A search for synergy } \\
\text { and fostering of cross- } \\
\text { border learning within } \\
\text { the corporation } \\
\text { - Turning Nordea into a } \\
\text { true MNC }\end{array}$ & $\begin{array}{l}\text { - Top managers of the } \\
\text { new } \\
\text { corporation }\end{array}$ \\
\hline $\begin{array}{l}\text { Nationalist } \\
\text { storytelling } \\
\text { Summer-fall } 2000\end{array}$ & $\begin{array}{l}\text { - Nordea is a crucial step } \\
\text { in the development of } \\
\text { national financial } \\
\text { services sectors. } \\
\text {. }\end{array}$ & $\begin{array}{l}\text { Promotion of national } \\
\text { interests, especially in } \\
\text { the distribution of top } \\
\text { positions, resource } \\
\text { allocation and cutback } \\
\text { decisions, and in choices } \\
\text { regarding systems and } \\
\text { practices }\end{array}$ & $\begin{array}{l}\text { - Middle and top } \\
\text { managers especially in } \\
\text { the context of } \\
\text { controversial issues } \\
\text { and decisions }\end{array}$ \\
\hline & $\begin{array}{l}\text { - The key challenge is to } \\
\text { protect national } \\
\text { identities and interests }\end{array}$ & $\begin{array}{l}\text { - Cross-national } \\
\text { comparisons and } \\
\text { stereotypes as a key part } \\
\text { of identity building }\end{array}$ & \\
\hline $\begin{array}{l}\text { Nordic storytelling } \\
\text { Fall 2000-summer } \\
2001\end{array}$ & $\begin{array}{l}\text { - Nordea is a unique } \\
\text { Nordic achievement that } \\
\text { builds on cross-border } \\
\text { collaboration. } \\
\text { - The key challenge is to } \\
\text { play down nationalism } \\
\text { and international } \\
\text { confrontation. }\end{array}$ & $\begin{array}{l}\text { - Promotion of Nordic } \\
\text { solutions (especially } \\
\text { positive experiences of } \\
\text { collaboration) } \\
\text { - Creating joint corporate } \\
\text { culture and new identity }\end{array}$ & $\begin{array}{l}\text { - Top managers and } \\
\text { other organizational } \\
\text { members focusing on } \\
\text { cultural integration } \\
\text { and new identity } \\
\text { building }\end{array}$ \\
\hline
\end{tabular}




\begin{tabular}{|l|l|l|l|} 
& & & \\
\hline $\begin{array}{l}\text { New globalist } \\
\text { storytelling }\end{array}$ & $\begin{array}{l}\text { - Nordea must be a } \\
\text { pioneer of the } \\
\text { globalization of } \\
\text { financial services. }\end{array}$ & $\begin{array}{l}\text { Prioritization of } \\
\text { shareholder value, } \\
\text { maximization of synergy } \\
\text { benefits, and preparation } \\
\text { for new cross-border } \\
\text { mergers and acquisitions }\end{array}$ & $\begin{array}{l}\text { - Managers aspiring } \\
\text { for more radical } \\
\text { change and rapid } \\
\text { globalization }\end{array}$ \\
& $\begin{array}{l}\text { The key challenge is } \\
\text { not to remain Nordic but } \\
\text { to move on. }\end{array}$ & $\begin{array}{l}\text { Moving from Nordic to } \\
\text { true global identity }\end{array}$ & \\
& & \\
\hline
\end{tabular}

\section{Nationalist Storytelling to Relegitimate National Identities and Interests}

The globalist storytelling was, however, challenged by increasing nationalism in the postmerger organization. According to our interview, observational, and documentary data, meetings between middle managers of the same nationality especially tended to involve nationalist interpretations and to legitimate nationalistic agendas. Middle managers, as well as some of the top managers, learned to use nationalistic framings when protecting interests in internal politics, for example, in negotiating the distribution of managerial positions, cutbacks, and resource allocation across the organizations in different countries. Such storytelling was often closely linked with the media coverage on the case .

Swedish Storytelling. The Swedish managers tended to represent themselves as the strategic leaders of MeritaNordbanken in 1997-2000 internally and externally (e.g., presentations and interviews in the media). In particular, the Swedish managers saw it as important to promote the banking models and systems that had been developed in the reconstruction of Nordbanken and refined in MeritaNordbanken. However, implementing their strategy was hampered by difficulties in integrating the Swedish and Finnish organizations at the MeritaNordbanken phase - something that also continued after the merger with Unidanmark. Adverse Finnish reactions toward some of the initiated changes were linked in the Swedish comments with the Finns" "sensitivity" and "nationalism"- as the Swedes frequently described their challenges. This was in turn said to be caused by the Finns' "Little Brother complex" with the Swedes, which can be traced to the postcolonial type of relationship between these countries. As a Swedish manager explained it, "Naturally, the Finns kept guard over it the most _ _ Sweden being a bigger country and all that." 
Although the merger with Finns had been challenging for Swedes, the merger with Unidanmark in 2000 was constructed in the Swedish storytelling as even more difficult. According to our interviews and observations, the negotiations with Danes prior to the merger were seen as "demanding" or "very difficult" by the Swedish negotiators. The distribution of top management positions was a particularly sensitive issue for the Swedes, who generally thought that the Danes "got too much." Furthermore, decisions concerning cutbacks in units managed by Danes provoked the Swedes. For example, it was decided early on that the operations of one of the large units in the bank were to be concentrated in Copenhagen (Denmark), which led to layoffs in Stockholm (Sweden). A theme frequently brought up by Swedes was the tendency of the Danes to engage in "politicking" that the Swedes often found "destructive" and "unfair."

Swedish top managers frequently referred to difficulties in coping with what they called the "Danish negotiation culture." Interestingly, in this context, Finns emerged as newfound allies in the Swedish storytelling. Unlike the Danes, Finns could be trusted: "Denmark has a Latin negotiation culture. I mean in Sweden and Finland we built it up logically," as one of our Swedish interviewees put it. Another explained it as follows: "But, to make a caricature and this is how the people talk in our organisation, when one meets a Danish colleague he says: 'I have changed this.' 'How the hell can you do that? We agreed we should _ _ _ 'Well yes, that was last week.' ",

Even though the acquisition of CBK was a lengthy project, the Norwegians were in general given less attention by the Swedes (e.g., in our observations of meetings and in our interviews). However, the Swedish managers were often amazed by the strong tendency of the Norwegian managers to "cling to their nationalism" when making decisions regarding CBK.

Finnish Storytelling. The Finnish managers often emphasized the pioneering role of the Finns in the process of creating the new multinational financial services company. In particular, the Finnish members of the corporate top management retold the following story time and again in various arenas: "The business concept covering all of the Nordic countries was part of the idea that we created back then [in December 1993] in the executive management of the Union Bank of Finland. We extended an invitation to others, banks operating in other countries." 
The making of Nordea also triggered a strong sense of international confrontation among the Finns. Initially, this was especially the case vis-à-vis the Swedes. For example, the Finns were frustrated with the Swedish tendency to promote their own solutions and practices. "Best practice is West practice" became a joke among the Finns, referring to the "know-all" Swedes as the West. Other anecdotal stories were also frequently told. A Finnish interviewee told the following story: "That Swede, who is no longer working for us, always started a meeting by saying, 'What we do in Sweden we are also planning to implement in Finland.' On one occasion, we got angry, and we said nothing. He started a sentence seven times by saying, 'What we do in Sweden we are also planning to implement in Finland.' Only after that did we feel pity for him and said that the law is different here, that is simply illegal here." When Danes came on board in 2000, however, Finns also started to promote allying with Swedes - the "dear enemies" - to combat Danish dominance. This was the case, for example, when dealing with national representation in top management. The stereotype of the "merchant" became a widely used cultural representation of the Danes that Finns (and Swedes) used to describe conflict situations. "There are more differences between the Danish culture vis-à-vis the Finnish and Swedish cultures then there are between the Finnish and Swedish cultures," a top manager remarked.

At times Finns could identify with the Norwegians as underdogs in the prevailing Nordea power struggles: "In a way, Danes and Swedes have a colonial attitude. They have somehow internalized that 'if I am a Dane or a Swede, I have specific importance.' "Yet the Finnslike the Swedes and Danes-were amazed by the strong nationalism of the Norwegians in negotiations concerning distribution of managerial responsibilities and decisions concerning resource allocation: "They are, most of all, Norwegians _ _ nationalistically oriented."

Danish Storytelling. The Danish managers, in turn, frequently portrayed Nordea as a logical follow-up to the aggressive growth strategy created in the Danish organization (e.g., in presentations and interviews). "It was to create a bigger unit, which would weigh more in the new context," a Danish manager described the domestic merger between Unibank and TrygBaltica in 1999. "On the Danish side, we wanted to have significant influence if we joined hands with someone."

The Danish managers frequently framed integration problems and challenges as "negotiation issues between Swedes and Danes," focusing less attention on Finns and Norwegians. 
Talking about themselves, many referred to situations where they had represented "a big challenge" to their colleagues from the other Nordic countries, who apparently perceived them as confrontational. From the Danish perspective, however, negotiation was only natural. As a Danish manager put it in an interview, "I know very well that some of my Finnish and Swedish colleagues would say that some Danish senior executives are very eager to fight. _ _ But I wish we would more often have the courage and dare to confront each other in order to test whether our ideas are indeed sustainable."

At the same time, Danish managers were amazed by the Swedish (and at times also the Finnish) negotiation and management styles, which appeared ineffective from their perspective. This was the case with decisions concerning new systems and models where the Danes wanted to promote their own solutions. The Danes were particularly eager to make others see the value in the integration of banking and insurance services. In this context, the conflict avoidance of the Swedes was difficult to understand. Norwegians, in turn, were treated in Danish storytelling as "occasional allies" in decision making. As a Danish manager put it, "I've heard people say that it is always easier for Danes and Norwegians to talk and do business together. Clearly, this is where the interaction between cultures functions best. There are no problems. We can understand each other."

Norwegian Storytelling. Finally, in the Norwegian nationalist storytelling, yet another view of Nordea was promoted. CBK was acquired in October 2000, after which the focus among the CBK managers shifted toward distribution of responsibility within Nordea. After the bidding process for acquiring CBK had been settled, it was important from the Norwegian perspective that their ex-CEO would have a key position in the top management: "Tom Ruud had to be given a prominent position so that the Norwegians would feel a welcome partner." It was also important that Norwegian expertise in areas such as oil and shipping was recognized and a center of excellence was to be built in Oslo, the Norwegian capital. "So internally we speak about a merger, which is in itself a political choice of words, to avoid having [CBK] be seen too much as a little brother or as an outsider," a Norwegian top manager told us in the interview.

Being the last to join in the Nordic constellation, Norwegian managers tended to make sense of issues in ways that emphasized their "outsider" position vis-à-vis the cross-national power struggles. At the same time, they frequently referred to confrontation. A Norwegian manager described the political situation in an interview: "It is the Danes and us on the one side and Finns and Swedes on the other on many occasions, both on matters related to organization 
and concepts. On the other hand, it is a bit like us three against the Danes on some occasions as well. Danes want to run things their way." At the same time, Norwegian managers often took the side of the Danes in national confrontations within the Nordea organization. As an interview put it, "In a way, we found our friends in the Danes. They are very much like us. But they are more cunning."

In all, nationalist storytelling provided an important counterweight to the official globalist storytelling. It is important to note that this storytelling was not only mere resistance to top management's globalist ante narratives but also a means to talk into being important national identities and interests in the merging organization. Interestingly, this nationalist storytelling was self reinforcing; the perceived nationalism of others tended to trigger one's own nationalist interpretations.

\section{Nordic Storytelling to Create New Identity}

Top management saw this growing nationalism as problematic, especially when dealing with cumbersome integration challenges such as distributing key management positions, integrating organizational structures and processes, ensuring motivation and commitment, and convincing investors and other stakeholders about the progress made. In discussions among top management at the end of 2000, a novel corporate identity and image was seen as a crucial means to promote integration and to alleviate the potential problems related to nationalism. After considering alternatives, top management decided to tap into Nordic imagery and values. An important part of the Nordic storytelling was the introduction of the Nordea name-derived from "Nordic" and "ideas"—in October 2000.

The identity-building program at Nordea included both internal and external storytelling. Internally, a great deal of effort was made to develop a new cultural identity - that is, new corporate values and their translation into common standards and daily practices-in line with the Nordea brand. A booklet describing the new Nordea identity and brand put it as follows: “As Nordea, we are not only breaking new ground. We are creating something quite unique. Nordea is not a conventional organization as it is spread throughout several countries and run from headquarters in Helsinki, Copenhagen, Oslo, and Stockholm" (Nordea 2001, p. $19)^{2}$

Externally, the Nordea brand (and the intended Nordic image) was introduced to the public in the spring of 2001. In this ad campaign, a Nordic identity was crafted to provide a meaningful basis for developing a common future for the new multinational financial services enterprise. 
The idea was to make use of distinctive positive images of the Nordic countries that were related to particular "Nordic values." Nordea advertisements published in major newspapers in the Nordic countries introduced a set of images and slogans: Nordic simplicity, Nordic opportunities, Nordic security, Nordic flexibility, Nordic freedom, and Nordic individuality. Interestingly, mobilization of the Nordic antenarratives focused on specific national images and icons to promote positive senses of Nordic heritage. For example, the ad campaigns included examples of icons and achievements such as the Danish designer Arne Jacobsen's egg-shaped chair and the Finnish architect Alvar Aalto's vase as well as the Swedish Tetra Pak's and the Norwegian company Stokke's innovations. Hence, the Nordic antenarratives existed in a dialogical relationship with the nationalistic interpretations, as storytelling intended precisely to steer attention from confrontation to joint heritage and future.

Internally, the Nordic antenarrative was used to create new ways to manage the integration process, for example, with the idea of "Nordic Champions," creation of "Nordic best practices," and establishment of "Nordic Competence Centers." A top manager described the approach as follows:

Within the organization, I really think [Nordic] has become a language that is being used. We have this theme we call the Nordic Champions, which has been talked about a lot. We've built this thing around it, in the development stage, and we still do that a lot. We've had these projects, and I'm not sure whether they've had any concrete significance, but they're part of promoting ...these Nordic ideas, that's behind the name Nordea, where the objective is to promote Nordic values.

On the whole, the international (regional) Nordic antenarrative soon became the new "official story" promoted by the corporate top management in internal and external communications. In fact, in official communications globalist and Nordic antenarratives were often tied together to create a specific international identity and image for the group. Decisions concerning postmerger integration at Nordea were legitimized by reference to the pan-Nordic identity. Key issues on integration included the idea of a "virtual headquarters," that is, a decision not to establish one official headquarters but to distribute responsibilities among all four Nordic countries. Group executive meetings were to take place once a week in either Copenhagen (Denmark), Helsinki (Finland), Stockholm (Sweden), or Oslo (Norway). This was a choice that effectively promoted the idea of equality between the different country organizations and nationalities in the Nordic constellation. As a top manager put it, "Work on the board of directors was built on the Nordic principle." 
Another important issue was the idea of equal representation in top management. In practice, most managers interpreted this as a general principle to be used in key appointments. A top manager explained it as follows:

Everyone basically understood that it was a new game now and that the team had to be picked again. It was necessary to evaluate who would fit in which position. ...It was a bit of tit-for-tat. For some, this obviously meant that they had to give up some Nordic responsibility when a Dane came along and took over. For others, however, this meant added responsibility with the Danes joining in. ...This is just the way it is. You just have to see that the whole thing functions.

In all, this Nordic storytelling proved to be an effective means for creating a new identity for the merging MNC. It reproduced the Nordic antenarratives that the media and other stakeholders had already used to make sense of the case in 1999-2000 but also had a major influence on the media coverage in 2001. Important for our purposes, this storytelling can be seen as a successful means for the corporate management to regain control of the new MNC.

\section{Globalist Storytelling as Critique of Nordism}

However, not all top managers were satisfied with the pronounced Nordic orientation. In particular, those members of the corporate management who were advocates of rapid and effective integration and globalization often reverted to new kinds of globalist storytelling. A typical example is provided by a top manager promoting European expansion: "We want to position ourselves among the 10 biggest in Europe, and signal growth that all would respect." Another key manager stated that "the next acquisition has to be European."

Globalist storytelling emphasized the need to move on, even if it meant drastic decisions that would trigger resistance or go against the espoused "Nordic values." In fact, deliberate promotion of globalist views often involved explicit downplaying or negation of Nordism, which was deemed old-fashioned or simply impossible to draw on in the global economy. Nordic thinking was blamed for "impeding the necessary restructuring process," as one of our interviewees put it. "Impeding" referred to, for example, the resistance that led to abandoning a planned merger with a major Dutch financial services group. Also, the idea of "equal representation" was heavily criticized within the corporation. A key manager put it as follows: "Democracy - if you can call it that - has been given higher priority than competence. There's an unbelievable number of examples where someone is chosen because he is of the right nationality rather than because of the right competences." His colleague noted that "no organization is able to live for long if you select [key people] on the basis of balance of 
power. _ _ _ The idea is always in the background that _ _ _ when we are really united, then the best person will be chosen for the job in question. Everyone knows that this stage will come, sooner or later."

The intentional Nordic focus in Nordea's strategy was at times deliberately ridiculed inside the organization. For example, in top management meetings the Nordic brand and identity was sometimes linked with the Nordic Council (a political cooperation institution of the Nordic countries, founded in 1952) or SAS (an airline owned by the Danish, Norwegian, and Swedish states and founded in 1946). In these comments, the Nordic Council was represented as the ultimate example of consensus-oriented discussion that does not lead to useful decisions, and SAS was seen as a loss-making corporation in which a governance system based on national representation has an adverse effect on profitability. "We do not want to be another SAS," a top manager explained in an interview.

In all, this storytelling echoed the globalist antenarratives that the media and other stakeholders circulated around the Nordea case but at the same time also explicitly attacked the Nordic identity-building efforts. Thus, this critique can be seen as a logical follow-up of the initial globalist storytelling by corporate management and also as resistance toward the imposed Nordic identity.

\section{Discussion: Antenarratives, Storytelling, and Dialogical Dynamics in Merging MNCs}

The Nordea merger is a revelatory case that helps us better understand the role of antenarratives and storytelling in organizational change processes. Our analysis leads to the following key conclusions. First, the analysis demonstrates the central role of globalist, nationalist, and regionalist antenarratives as discursive cultural resources. The point is that these are not arbitrary discourses but constitutive elements of MNCs as institutions and organizations. As our analysis shows, they are resources that "circulate" in and around MNCs and should thus be taken seriously in discursive analyses of MNCs (Geppert 2003, Frenkel 2008, Jack et al. 2008, Vaara and Tienari 2008).

Second, the analysis illustrates how storytelling that mobilizes these antenarratives is an inherent part of unfolding change processes in merging MNCs. In particular, our analysis helps to connect discourse with action in a manner that elucidates the performative power of discourse in change. The Nordea case is specific in the sense that we can point to successive storytelling efforts where globalist, nationalist, Nordic, and again globalist antenarratives 
were used to legitimate or resist change. Nevertheless, such storytelling-even if not as salient as in this case - is also likely to characterize other settings.

Third, this analysis elucidates the dialogical dynamics in unfolding change processes. In particular, by opening up the dialogical perspective, our analysis contributes to a better understanding of legitimation and resistance in merging MNCs - two themes that have too often been kept apart in previous literature. It is important to note that legitimation in this view is not only about justification of planned changes but more about talking new ideas, identities, and interests into being, which is a broader perspective than is typically adopted in studies of legitimation (Kostova and Zaheer 1999, Kostova et al. 2008, Deephouse and Suchman 2008). Likewise, in this view resistance is not limited to counterarguments to top management's initiatives but includes voicing concerns by alternative narratives (Ford et al. 2008, Thomas et al. 2010). By mapping out the dialogical relationships between successive storytelling efforts in the Nordea case, this analysis thus adds to the conventional views on change and resistance in MNC and other contexts.

Fourth, the analysis specifically helps us better understand the nature of polyphonic, stylistic, chronotopic, and architectonic dialogisms. By so doing, our study clarifies the value of Bakhtian-inspired analysis in discourse-cultural studies of organizations and extends Boje's (2008) work in this area. In particular, our study shows how important it is to focus attention on polyphony in organizational change. The crucial point is that a careful mapping of storytelling reveals how actors use their voice to articulate specific ideas, identities, and interests and how others then react to the storytelling with their own views. In the Nordea case, the globalist antenarratives were a means for top management to legitimate the merger and to create a new MNC identity. In turn, the nationalist antenarratives were a means to relegitimate national identities and interests. Then again, the regionalist Nordic antenarratives were used to promote a new pan-Nordic identity and to talk Nordic interests into being. Finally, new versions of the globalist antenarratives were mobilized by critical managers to promote more radical changes and internationalization. Such polyphony may be particularly salient in the Nordea case, but we suggest that such dialogisms are also likely to characterize other MNCs.

This case also shows the importance of stylistic dialogisms. In brief, the various stylistic expressions of the antenarratives and the related modes of semiosis all contributed to the complex and ambiguous narrative understandings of the new MNC. Our analysis shows how storytelling unfolded in and through press releases, presentations, conversations in meetings, 
comments in informal discussions, visual images, and so forth. Importantly, specific antenarratives could be more naturally expressed by particular channels and styles than others. For example, corporate management's "official" storytelling was mediated by a wide range of communication channels, whereas the "less legitimate" nationalist storytelling or critique of top management usually had to be expressed through informal channels, often by using styles such as irony as in the case of nationalist antenarratives and critical globalist storytelling. Thus, we can see how this storytelling is linked with and unfolds through different genres (Levina and Orlikowski 2009).

The Nordea case also underscores the importance of chronotopes - that is, specific timespace representations (Bakhtin 1981, Hazen 1993). Our analysis demonstrates how antenarratives constructed different understandings of the past, present, and future and placed the MNC and the ongoing changes in different contexts. For example, in the globalist antenarratives, the outlook was future-oriented, and the changes in and around the MNC were placed in a wider global context. Nationalist antenarratives in turn drew from age-old historical representations that can ultimately be linked with the colonial histories of the nations in question. In contrast to the global antenarratives, nationalist antenarratives tended to reduce space to refocus on national identities and interests in the new MNC. The regionalist Nordic antenarratives are then interesting constructions in the sense that they drew from the historical past but focused on a specific regional space.

We must also emphasize the architectonic — aesthetic and ethical-dialogisms in storytelling in and around Nordea. The crucial point is that the globalist, nationalist, and Nordic antenarratives provided very different kinds of grounds for defining what is seen as appropriate, legitimate, and natural. At a fundamental level, globalist antenarratives are linked with neoliberalism and global capitalism as the ideological basis (Fairclough 1999). In turn, nationalist interpretations are based on nationalism as discourseand ideology (Billig 1995). Finally, Nordism can be seen as an expression of regionalism that resembles attempts to create specific European identities (Breakwell and Lyons 1996). Paying attention to this architectonic level is crucial for an understanding of why these different antenarratives needed to be expressed in the unfolding change processes at Nordea; they provided a way to legitimate specific, alternative views on what was important or not, right or wrong, a duty or not.

Fifth, and finally, storytelling in the unfolding change processes also constitutes heteroglossia: interplay of centripetal (centering) and centrifugal (decentering) forces (Boje 2008). This 
heteroglossia can be seen as the discursive dimension of control-resistance dynamics in MNC organizations - a conceptualization that is useful to focus attention on the ways in which discourse and power are intertwined in MNCs (Clegg et al. 2008, Kristensen and Zeitlin 2005). In the Nordea case, much of what happened can be understood by top management's attempts to control meanings and interpretations that were then challenged by alternative decentering meanings and interpretations. In brief, the corporate management first focused on the globalist framings to push for specific kinds of justifications and identity markers and not others. This was, however, challenged by various kinds of nationalist interpretations providing an array of decentering alternative interpretations. These decentering antenarratives created a need for the corporate management to regain control, which it did through the purposeful Nordic identity-building campaign - a launch of specific predefined understandings of what Nordea was and should be. Finally, this was again resisted by others - in particular, by the decentering interpretations and alternative framings of critical managers.

\section{Conclusion}

Extant research provides several frameworks that help us to understand the role of discourse in the cultural construction of organizational life: cultural toolkits (Swidler 1986, Weber 2005), vocabularies (Weick 1995, Geppert 2003), frames (Goffman 1974, Fiss and Hirsch 2005), and genres (Orlikowski and Yates 1994, Levina and Orlikowski 2009). We have argued that it is important to complement this stream of research by elucidating how narratives and storytelling are used in cultural constructions, especially in times of change. The point is that narratives are the means to construct identities and interests in time and space; this is a key aspect of discursive constructions that other discourse-cultural approaches cannot fully address (Barry and Elmes 1997, Czarniawska 2004, O’Connor 2003). Rather than applying conventional narrative analysis (Gabriel 2000), we have drawn from antenarrative analysis (Boje2001, 2008) and developed it further for the analysis of organizational change. This is because the antenarrative approach allows one to zoom in on organizational narratives that are usually fragmented pieces of discourse as well as on the processes of storytelling, the dynamics of which easily pass unnoticed in more conventional narrative analysis. This perspective is certainly not the only approach for achieving a better understanding of narratives and storytelling (Ibarra and Barbulescu 2010, Martens et al. 2007, Sonenshein 2010), but it does explain how some stories become widely spread narratives, how intentional storytelling draws from and reproduces such narratives, and how all this 
connects with unfolding organizational change. Although we have applied this new perspective to merging MNCs, we believe that it can-with due caution-also be used in other areas of cultural organizational analysis.

The special contribution of our empirical analysis is that it helps to better understand the dialogical processes in organizational storytelling. It demonstrates that stories can coexist in dialogical relationships, a phenomenon that has not been given much attention in previous research. Nevertheless, such a dialogical perspective has great potential to explain organizational change processes and the ways they unfold over time. It seems fruitful to develop dialogical views on organizational change in addition to the more dominant linear or dialectical views (Deetz 1996, Seo and Creed 2002, van de Ven and Poole1995). This is especially the case for discourse-cultural analyses that deal with complex, ambiguous, and contradictory phenomena. In particular, our analysis of the polyphonic, stylistic, chronotopic, and architectonic dialogisms as well as heteroglossia elucidates the dynamics involved in a way that cannot be grasped with more static discourse-cultural approaches. By so doing, our study illustrates the value of Bakhtian-inspired antenarrative analysis for cultural studies of organizations more generally.

This paper has specific implications for research on MNCs (Morgan et al. 2001, Kostova and Zaheer 1999, Kostova et al. 2008, Kristensen and Zeitlin 2005). In particular, our analysis adds to knowledge of the discursive and narrative construction of multinational organizations (Geppert 2003, Frenkel 2008, Jack et al. 2008, Vaara and Tienari 2008). We have demonstrated that globalist, nationalist, and regionalist antenarratives are not arbitrary but are constitutive elements of MNCs as organizations and institutions. We have also argued that their mobilization is intimately linked with the legitimation of and resistance to change as well as with more general control-resistance dynamics in these complex organizations. Our analysis shows that although one tends to associate MNCs primarily with globalization, nationalism also plays a crucial role, even though it has rarely received explicit attention from MNC scholars (Geppert 2003, Brannen 2004, Frenkel 2008). Finally, our findings concerning regionalism should also be taken seriously (Breakwell and Lyons 1996), at least as examples of how regional identities and interests may be created to complement the simplistic dialogue between globalization and nationalism.

This paper also has implications on research on mergers and acquisitions. "Cultural differences" have often been used as explanations of problems and failures in international mergers and acquisitions (Olie 1994, Vaara 2002, Stahl and Mendenhall 2005). Recent 
studies have broadened this perspective by emphasizing the role of discourse in identity building (Ailon-Suday and Kunda 2003, Maguire and Phillips 2008). Furthermore, other analyses have demonstrated how discursive legitimation struggles often characterize international mergers (Tienari et al. 2003, Vaara et al. 2006, Vaara and Monin 2010). Our analysis adds to these studies by providing a new way of conceptualizing mergers and acquisitions as storytelling processes. Unlike the conventional views on communication, our analysis demonstrates that such storytelling is an inherent part of the unfolding merger process. This storytelling is not only carried out by top management but also involves other actors. The resulting view is thus not a monologue but a continuous dialogue and multilogue, which in itself tends to impact future storytelling. These forms of alternative storytelling can be theoretically linked with a broad conception of organizational resistance (Thomas et al. 2010). However, researchers often fail to discover the alternative storytelling efforts that do not involve the "official" communication channels. We believe that this dynamic view on storytelling can pave the way for new understandings of postmerger integration and also furthers understanding of the frequent problems and failures in postmerger change processes.

Our analysis has limitations that should be taken seriously. This is a specific case, and many of its features are unique. The particular forms of nationalism and Nordic regionalism analyzed in this paper have characteristics that are not found in other cultural settings. Nevertheless, we believe that globalist, nationalist, and regionalist antenarratives are likely to circulate around other cases and that merger processes are usually characterized by more or less intentional storytelling involving dialogical dynamics. Also, it should be noted that we have only uncovered some aspects of the myriad of antenarratives that characterized the Nordea case within the space of this article. Thus, the antenarratives and storytelling efforts may appear more linear or straightforward than a more nuanced analysis could reveal.

This paper opens up new avenues to examine the discourse-cultural construction of organizations. As discussed above, we believe that the antenarrative approach outlined here can be applied to various areas of culturally oriented organizational research. Although we have focused on MNCs and mergers and acquisitions, future studies could focus on other contexts and phenomena. It seems especially important to apply and further refine the dialogical view on organizational change. Our analysis has concentrated on the general characteristics of antenarratives to understand their mobilization and dialogical coexistence, but future studies can go further in terms of analysis and comparison of antenarratives and storytelling in specific contexts. To gain a more in-depth understanding of the underlying 
microprocesses, future research can focus on particular dialogical dynamics-for example, chronotopic and architectonic/ideological dialogisms. Such analysis could use methods such as frame analysis (Benford and Snow 2000, Johnston and Noakes 2005) or critical discourse analysis (Fairclough 2003, Phillips et al. 2004) to be able to focus on the textual micro level. There is also a need to better understand how exactly linguistic articulations are linked with other social practices. This could be done for example by combining antenarrative analysis with the study of genre repertoires (Levina and Orlikowski 2009). Finally, it would be important to go further in the critical analysis of discourse and culture in MNC and other organizations. This study has demonstrated how antenarratives and storytelling are linked with identity and legitimacy, but future work could go further in analyzing the various ways in which widely spread stories and storytelling are linked power structures and ideological representations.

\section{Acknowledgments}

The authors are very grateful to Tina Dacin, Klaus Weber, and the anonymous reviewers for excellent comments and very helpful advice. This paper is based on a pan-Nordic research project. The authors thank colleagues Ingmar Björkman, Karl-Olof Hammarkvist, Charlotte Holgersson, Tore Hundsnes, Christine B. Meyer, Annette Risberg, and Anne-Marie Søderberg for extremely fruitful collaboration. Furthermore, they express their gratitude to Eric Breit, Katja Peltola, and Tina Karme for helping with the coding; David Miller for the language revision; and Pikka-Maaria Laine and Saku Mantere for very helpful comments and support throughout the process.

\section{Endnotes}

${ }^{1}$ Merger Prospectus relating to the proposed merger of MeritaNordbanken and Unidanmark (March 23, 2000), http://www.nordea.com/sitemod/upload/Root/www.nordea.com\%20-

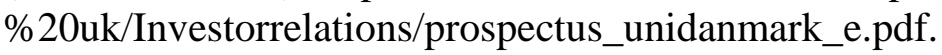

${ }^{2}$ Nordea. 2001. Making it possible. Booklet distributed to all Nordea employees.

\section{References}

Ailon, G. 2008. Mirror, mirror on the wall: Culture's consequences in a value test of its own design. Acad. Management Rev. 33(4) 885-904.

Ailon-Souday, G., G. Kunda. 2003. The local selves of global workers: The social construction of national identity in the face of organizational globalization. Organ. Stud. 24(7) 1073-1096.

Anderson, B. 1983. Imagined Communities: Reflections on the Origin and Spread of Nationalism. Verso, London. 
Bakhtin, M. M. 1981. The Dialogic Imagination. M. Holquist, ed. University of Texas Press, Austin.

Bakhtin, M. M. 1984. Problems of Dostoevsky's Poetics. C. Emerson, ed. Translated by C. Emerson. University of Minnesota Press, Minneapolis.

Bakhtin, M. M. 1986. Speech Genres and Other Late Essays. M. Holquist, ed. Translated by C. Emerson. University of Texas Press, Austin.

Barry, D., M. Elmes. 1997. Strategy retold: Toward a narrative view of strategic discourse. Acad. Management Rev. 22(2) 429-452.

Benford, R. D., D. A. Snow. 2000. Framing processes and social movements: An overview and assessment. Annual Rev. Sociol. 26 611-639.

Bhabha, H. K. 1990. Nation and Narration. Routledge, London.

Bhagwati, J. 1991. The World Trading System at Risk. Princeton University Press, Princeton, NJ.

Billig, M. 1995. Banal Nationalism. Sage, London.

Boje, D. M. 1995. Stories of the storytelling organization: A postmodern analysis of Disney as "Tamara-land." Acad. Management J. 38(4) 997-1035.

Boje, D. M. 2001. Narrative Methods for Organization and Communication Research. Sage, New York.

Boje, D. M. 2008. Storytelling Organizations. Sage, London.

Boje, D. M., R. C. Alvarez, B. Schooling. 2001. Reclaiming story in organization:

Narratologies and action sciences. R. Westwood, S. A. Lindstead, eds. The Language of Organization. Sage, London, 132-175.

Boje, D. M., G. A. Rosile, R. A. Durant, J. T. Luhman. 2004. Enron spectacles: A critical dramaturgical analysis. Organ. Stud. 25(5) 751-774.

Brannen, M. Y. 2004. When Mickey loses face: Recontextualization, semantic fit, and the semiotics of foreignness. Acad. Management Rev. 29(4) 593-616.

Breakwell, G. M., E. Lyons, eds. 1996. Changing European Identities: Social Psychological Analyses of Social Change. Butterworth-Heinemann, Oxford, UK.

Brown, A. D., M. Humphreys. 2003. Epic and tragic tales: Making sense of change. J. Appl. Behav. Sci. 39(2) 121-144.

Buono, A. F., J. L. Bowditch. 1989. The Human Side of Mergers and Acquisitions: Managing Collisions Between People, Cultures, and Organizations. Jossey-Bass, San Francisco.

Clegg, S., D. Courpasson, N. X. Phillips. 2008. Power and Organizations. Sage, London.

Cooper, D. J., R. Greenwood, B. Hinings, J. L. Brown. 1998. Globalization and nationalism in a multinational accounting firm: The case of opening new markets in Eastern Europe. Accounting, Organ. Soc. 23(5) 531-548.

Czarniawska, B. 1997. Narrating the Organization: Dramas of Institutional Identity. University of Chicago Press, Chicago.

Czarniawska, B. 2004. Narratives in Social Science Research. Sage, London. 
Deephouse, D. L., M. Suchman. 2008. Legitimacy in organizational institutionalism. R. Greenwood, C. Oliver, K. Sahlin, R. Suddaby, eds. The Sage Handbook of Organizational Institutionalism. Sage, Thousand Oaks, CA, 49-77.

Deetz, S. 1996. Describing differences in approaches to organization science: Rethinking Burrell and Morgan and their legacy. Organ. Sci. 7(2) 191-207.

Demers, C., N. Giroux, S. Chreim. 2003. Merger and acquisition announcements as corporate wedding narratives. J. Organ. Change Management 16(2) 223-242.

Fairclough, N. 1999. Global capitalism and critical awareness of language. Language Awareness 8(2) 71-83.

Fairclough, N. 2003. Analysing Discourse: Textual Analysis for Social Research. Longman, London.

Fiss, P. C., P. M. Hirsch. 2005. The discourse of globalization: Framing and sensemaking of an emerging concept. Amer. Sociol. Rev. 70(1) 29-52.

Ford, J. D., L. W. Ford, A. D'Amelio. 2008. Resistance to change: There st of thestory . Acad. Management Rev. 33(2) 362-377.

Frenkel, M. 2008. The multinational corporation as a third space: Rethinking international management discourse on knowledge transfer through Homi Bhabha. Acad. Management Rev. 33(4) 924-942.

Gabriel, Y. 2000. Storytelling in Organizations. Facts, Fictions and Fantasies. Oxford University Press, Oxford, UK.

Geppert, M. 2003. Sensemaking and politics in MNCs: A comparative analysis of vocabularies within the global manufacturing discourse in one industrial sector. $J$. Management Inquiry 12(4) 312-329.

Goffman, E. 1974. Frame Analysis: An Essay on the Organization of Experience. Northeastern University Press, Boston.

Greenwood, R., C. R Hinings, J. Brown. 1994. Merging professional service firms. Organ. Sci. 5(2) 239-257.

Greimas, A. J. 1987. On Meaning: Selected Writings in Semiotic Theory. Frances Pinter, London.

Guillén, M., F. 2000. Is globalization civilizing, destructive or feeble? A critique of five debates in the social science literature. Annual Rev. Sociol. 27 235-260.

Haspeslagh, P. C., D. B. Jemison. 1991. Manageing Acqisitions, Creating Value Through Corporate Renewal. Free Press, New York.

Hazen, M. A. 1993. Towards polyphonic organization. J. Organ. Change Management 6(5) $15-26$.

Hellgren, B., J. Löwstedt, L. Puttonen, J. Tienari, E. Vaara, E. A. Werr. 2002. How issues become (re)constructed in the media: Discursive practices in the AstraZeneca merger. British J. Management 13(2) 123-140.

Hobsbawm, E. J. 1990. Nations and Nationalism Since 1780: Programme, Myth, Reality. Cambridge University Press, Cambridge,UK.

Hofstede, G. 1980. Culture's Consequences: International Differences in Work-Related Values. Sage, London. 
Ibarra, H., R. Barbulescu. 2010. Identity as narrative: Prevalence, effectiveness and consequences of narrative identity work in macro work roletransactions. Acad. Management Rev. 35(1) 135-154.

Jack, G. 2004. Language(s), intercultural communication and the machinations of global capital: Towards a dialectical critique. Language Intercultural Comm. 4(3) 121-133.

Jack, G., M. B. Calás, S. M. Nkomo, T. Peltonen. 2008. Critique and international management: An uneasy relationship? Acad. Management Rev. 33(4) 870-884.

Johnston, H., J. A. Noakes, eds. 2005. Frames of Protest: Social Movements and the Framing Perspective. Rowman \& Littlefield, Lanham, MD.

Kostova, T., T. Zaheer. 1999. Organizational legitimacy under conditions of complexity: Thecaseof themultinational enterprise. Acad. Management Rev. 24(1) 64-81.

Kostova, T., K. Roth, T. Dacin. 2008. Institutional theory in the study of multinational corporations: A critiqueand new directions. Acad. Management Rev. 33(4) 994-1006.

Kristensen, P. H., J. Zeitlin. 2005. Local Players in Global Games: The Strategic Constitution of a Multinational Corporation. Oxford University Press, Oxford, UK.

Langley, A. 1999. Strategies for theorizing from process data. Acad. Management Rev. 24(4) 691-710.

Larsson, R., S. Finkelstein. 1999. Integrating strategic, organizational, and human resource perspectives on mergers and acquisitions: A case survey of synergy realization. Organ. Sci. 10(1) 1-27.

Leonardi, P. M., M. H. Jackson. 2004. Technological determinism and discursive closure in organizational mergers. J. Organ. Change Management 17(6) 615-631.

Leung, K., R. S. Bhagat, N. R. Buchan, M. Erez, C. B. Gibson. 2005. Culture and international business: Recent advances and their implications for future research. J. Internat. Bus. Stud. 36(4) 357-378.

Levina, N., W. J. Orlikowski. 2009. Understanding the shifting power relations within and across organizations: A critical genre analysis. Acad. Management J. 52(4) 672-703.

Lubatkin, M., R. Calori, P. Very, J. F. Veiga. 1998. Managing mergers across borders: A two-nation exploration of a nationally bound administrative heritage. Organ. Sci. 9(6) 670 684.

Maguire, S., N. Phillips. 2008. "Citibankers" at Citigroup: A study of the loss of institutional trust after a merger. J. Management Stud. 45(2) 372-401.

Martens, M. L., J. E. Jennings, P. D. Jennings. 2007. Do the stories they tell get them the money they need? The role of entrepreneurial narratives in resource acquisition. Acad. Management J. 50(5) 1107-1132.

Miles, M. B., A. M. Huberman. 1994. Qualitative Data Analysis: An Expanded Sourcebook. Sage, Thousand Oaks, CA.

Morgan, G., P. H. Kristensen, R. Whitley. 2001. The Multinational Firm: Organizing Across Institutional and National Divides. Oxford University Press, Oxford, UK.

O'Connor, E. 2003. Plotting the organization: The embedded narrative as a construct for studying change. J. Appl. Behav. Sci. 36(2) 174-192. 
Olie, R. 1994. Shades of culture and institutions in international mergers. Organ. Stud. 15(3) 381-405.

Orlikowski, W. J., J. Yates. 1994. Genre repertoire: The structuring of communicativepractice s in organizations. Admin. Sci. Quart. 39(4) 541-574.

Phillips, N., T. B. Lawrence, C. Hardy. 2004. Discourse and institutions. Acad. Management Rev. 29(4) 635-652.

Riad, S. 2005. The power of "organizational culture" as a discursive formation in merger integration. Organ. Stud. 26(10) 1529-1554.

Rugman, A. M., A. Verbeke. 2004. A perspective on regional and global strategies of multinational enterprises. J. Internat. Bus. Stud. 35(1) 3-18.

Schweizer, L. 2005. Organizational integration of acquired biotechnology companies into pharmaceutical companies: The need for a hybrid approach. Acad. Management J. 48(6) 1051-1074.

Schweiger, D. M., A. S. DeNisi. 1991. Communication with employees following a merger: A longitudinal field experiment. Acad. Management J. 34(1) 110-135.

Seo, M.-G., W. E. D. Creed. 2002. Institutional contradictions, praxis, and institutional change: A dialectical perspective. Acad. Management Rev. 27(2) 222-247.

Shaver, J. M. 2006. A paradox of synergy: Contagion and capacity effects in mergers and acquisitions. Acad. Management Rev. 31(4) 962-976.

Sonenshein, S. 2010. We're changing - Or are we? Untangling the role of progressive, regressive, and stability narratives during strategic change implementation. Acad. Management J. 53(3) 477-512.

Stahl, G. K., M. E. Mendenhall. 2005. Mergers and Acquisitions: Managing Culture and Human Resources. Stanford University Press, Stanford, CA.

Stahl, G. K., A. Voigt. 2008. Do cultural differences matter in mergers and acquisitions? A tentative model and examination. Organ. Sci. 19(1) 160-176.

Swidler, A. 1986. Culture in action: Symbols and strategies. Amer. Sociol. Rev. 51(2) 273286.

Thomas, R., L. D. Sargent, C. Hardy. 2010. Managing organizational change: Negotiating meaning and power-resistance relations. Organ. Sci., ePub ahead of print March 25, http://orgsci.journal.informs.org/cgi/content/abstract/orsc.1090.0520v1.

Tienari, J., E. Vaara, I. Björkman. 2003. Global capitalism meets national spirit: Discourses in media texts on a cross-border acquisition. J. Management Inquiry 12(4) 377-393.

Tsoukas, H. 1989. The validity of idiographic research explanations. Acad. Management Rev. 14(4) 551-561.

Vaara, E. 2002. On thediscursi veconstruction of success/failure in narratives of post-merger integration. Organ. Stud. 23(2) 213-250.

Vaara, E., P. Monin. 2010. A recursive perspective on discursive legitimation and organizational action in mergers and acquisitions. Organ. Sci. 21(1) 3-22.

Vaara, E., J. Tienari. 2008. A discursive perspective on legitimation strategies in MNCs. Acad. Management Rev. 33(4) 985-993. 
Vaara, E., J. Tienari, J. Laurila. 2006. Pulp and paper fiction: On the discursivele gitimation of global industrial restructuring. Organ. Stud. 27(6) 789-810.

Van de Ven, A. H., M. S. Poole. 1995. Explaining development and changein organizations. Acad. Management Rev. 20(3) 510-540.

Van Maanen, J. 1988. Tales of the Field: On Writing Ethnography. University of Chicago Press, Chicago.

Van Maanen, J., J. Sørensen, T. R. Mitchell. 2007. The interplay between theory and method. Acad. Management Rev. 32(4) 1145-1154.

Weber, K. 2005. A toolkit for analyzing corporate cultural toolkits. Poetics 33(3-4) 227-252.

Weick, K. E. 1995. Sensemaking in Organizations. Sage, Thousand Oaks, CA.

Yin, R. K. 2005. Case Study Research: Design and Methods. Sage, Thousand Oaks, CA. 